\title{
Hebrew, Hebrews, Hubris?: Diagnosing Race and Religion in the Time of COVID-19
}

\author{
Richard Newton
}

Citation: Newton, Richard. 2021 Hebrew, Hebrews, Hubris?: Diagnosing Race and Religion in the Time of COVID-19. Religions 12: 1020 https://doi.org/10.3390/rel12111020

Academic Editors: Joel Baden and Antony W. Alumkal

Received: 15 July 2021

Accepted: 16 November 2021

Published: 19 November 2021

Publisher's Note: MDPI stays neutral with regard to jurisdictional claims in published maps and institutional affiliations.

Copyright: (C) 2021 by the author. Licensee MDPI, Basel, Switzerland. This article is an open access article distributed under the terms and conditions of the Creative Commons Attribution (CC BY) license (https:// creativecommons.org/licenses/by/ $4.0 /)$.
Department of Religious Studies, University of Alabama, Tuscaloosa, AL 35406, USA; rwnewton@ua.edu

\begin{abstract}
This thought experiment in comparison ponders a Black man's conviction that his Hebrew identity would make him immune to COVID-19. Surfacing the history of the claims and the scholar's own suspicions, the paper examines the layered politics of identification. Contra an essentialist understanding of the terms, "Hebrew" and "Hebrews" are shown to be classificatory events, ones imbricated in the dynamics of racecraft. Furthermore, a contextualization of the "race religion" model of 19th century scholarship, 20th century US religio-racial movements, and the complicated legacy of Tuskegee in 21st century Black vaccine hesitancy help to outline the need for inquisitiveness rather than hubris in matters of comparison. In so doing, this working paper advances a model of the public scholar as a questioner of categories and a diagnostician of classification.
\end{abstract}

Keywords: religion; race; Hebrew; comparison; ethnicity; COVID-19; public scholarship; classification; identity; Tuskegee

\section{Introduction}

On 11 March 2020, I took my car to the dealership for some routine maintenance. I expected my appointment to take no more than a couple of hours, but the automobile technician servicing my vehicle informed me that I would be better off returning to my office. Discoveries during the initial diagnostic check warranted a deeper examination of the condition of my thirteen-year-old car. So I availed myself of the dealership's courtesy shuttle.

Owning a car of that vintage, I am no stranger to the courtesy shuttle. And in the American South, I have learned it to be, without fail, a fascinating ethnographic experience. Maintaining the veneer of hospitality and niceness is a cultural expectation. But in Alabama, a short trip like that is a social experiment where strangers act out what they think is required. The vehicle becomes a centrifuge for social identities formed in historical contingency, harnessed in cultural negotiation, and protected in shells of assumption. Our essentialized projections of self move through the cultural plasma of custom until we bounce off each other within the confines of the vehicle. Meanwhile, the radio, the blurs in the window, the objects in the mirror only accelerate the collision within.

Social confinement can bring the kind of disarray that lays bare the pathologies that make us grow complacent. In this way, this particular encounter did not disappoint. The courtesy vehicle is an example of what religious studies scholar Laurie L. Patton calls an "eruptive public space", a genre of "discourse that interrupts and refuses to follow the implicit or explicit rules governing established public spheres" (Patton 2019, p. 10). For the scholar of religion, these spaces are occupational hazards that test our ethical and intellectual commitments to the very people we study. They remind us of who we all are and what we are working with.

Scholars have told many a tale to conceal their profession from inquisitive strangers, but this bashfulness can be as problematic as the insistence that we are the arbitrators of orthodoxy (Patton 2019, pp. 248-49). Both are symptoms of a dishonest elitism regarding the social formation that is "religion", and our relationship to it. Our analysis must account 
not only for the positionality of the scholar and a sophisticated treatment of our object of study, but also "the multidimensional self or multiplicity of selves" that we abbreviate out of convenience (Harrison 2008, p. 129). And in this working paper, I wish to return to one such incident that, at least to me, underscores what a critical examination of our layered identificatory obfuscations can accomplish.

On this particular trip in the courtesy vehicle, I was driven by an older Black gentleman. When I told him that I worked as a professor at the University of Alabama, he could not hide what I took to be surprise. Though he had driven many of my colleagues on his trips through our college town, he seemed taken aback that I could be a faculty member there. He was old enough to have witnessed the university's integration, but to see a younger Black professor is still an uncommon sight. And when he learned that I was a professor of religion, he nodded in affirmation, as if to signal that he was familiar with the subject of my expertise.

In the midst of our chit chat about current events, we listened to a program on National Public Radio (NPR) that detailed the onset of a novel coronavirus. A month prior, the World Health Organization (WHO) and the United States government had declared SARS-Cov-2 a public health emergency due to the rapid transmission and rising death count. We then heard WHO Director General Tedros Adhanom Ghebreyesus refer to the spread of COVID19 as a "global pandemic" (Keaten et al. 2020). For a brief moment, we let our mutual silence fade as if to let the startling news sink in in its own time. Then, the gentleman turned to me with a wink and a whisper:

"You know that won't get us, right? We're Hebrews, you know".

As one who has written, taught, and lectured on the importance of scholarly distance, I will admit that these words got the best of me. I was angered by the dangerous hermeneutical regime to which this man had pledged. I was bewildered as to how I might respectfully steer my elder toward a more informed perspective-as if any of us knew anything about the complexities of COVID-19 then. And frankly, I feared how the virus, and our society's response to it, would disproportionately disenfranchise people like us, as was so often the case in the racial history of U.S. public health (Lavizzo-Mourey and Williams 2016). Maybe I felt guilty or inhibited for being the wrong kind of doctor, but the incident in the courtesy vehicle moved me to hold fast to that with which I was most certain: that even if we Black people were Hebrews, the virus would not simply pass over us on account of that identification.

My scholarly drive for critical clarity was replaced by what was clearly the arrogant thinking, the hubris, of one with everything to teach and nothing to learn. I had adopted the kind of interpretive double-talk that managed to "preside over a slave trade that defined the human as chattel while at the same time evoking the language of democratic freedoms ... speaks of inalienable rights while practicing colonialism ... evokes the notion of reason while creating the repressive categories of race". And for all that knowledge, I remained none the wiser (Long [1993] 2018, p. 405).

It was a typical modern moment, historian of religion Charles H. Long might say, "a time in which the connection between the body and language, the body and exchange, and the body and the intellect was subverted" (Long [1993] 2018, p. 405). The interpreter and the interpretation, for all intents and purposes, had become indistinguishable. And as one often does, I let the moment pass and the conversation respectfully move on.

In the months to come, I have wondered how I could have shown greater scholarly acumen. How could I have leveraged my expertise to "make visible the highly normative aspects of the dominant discourse about religion, religions, and world religions-and to show who actually benefits from and who loses by these dominant ways of conceptualizing religion/s" (Alberts 2020, p. 210)? What if I were to somehow have used the exchange to probe the social formations that not only led to the driver's statement, but my reactions to them?

Patton suggests that this "different kind of imagining about religion" - that is, a real time theorizing in eruptive public spaces-might best be achieved by a scholarly 
willingness to play the revelatory role of "the wise fool", whose ignorance becomes a vehicle for pursuing greater knowledge. Patton's fool refers to the archetypal figures "that move between worlds and convey unutterable or difficult things as guests from another world ... operators within a world of questioning, abuse, invective and innuendo" (Patton 2019, pp. 25-26). If our sophomoric meanderings were to trespass over and against common sense, we might arrive at a study of religion where "the power struggle is acknowledged and the necessity of debate and controversy is real" (Patton 2019, p. 249). Scholars could then suffer the intricacies of generality and falsehood to determine the extent to which any of us know what we are talking about in the modern moment.

Jonathan Z. Smith's theoretical essay "Religion, Religions, Religious" once fostered such a eureka moment about the social politics of categories before readers regrettably distilled its nuanced thesis into maxims about the futility of defining religion (Smith [1998] 2004, pp. 179-98). That kind of obtuse reading would just as easily have us forget that the epithet "Uncle Tom" and the thesis of Uncle Tom's Cabin make the strangest of bedfellows (Martin 2008; Turner 1994, p. 73). And yet, as Bruce Lincoln writes, it is the juxtaposition of apples and "origins", where we come to understand what "passes for knowledge", for "meaning is constructed through contrast" (Lincoln 2018, p. 25).

I hazard to think that a more sophomoric response was in order than my scholarly pride would allow at the time. Scholarly redescription is an exercise in contrast, what Christopher M. Driscoll and Monica R. Miller call "categorical miscegenation". It is "the strategic practice of decontextualizing a category from its structured location and replacing it with a seemingly disparate category, so as to elucidate the structural social relation between categories" (Driscoll and Miller 2019, pp. 161-62).

What if I had inhabited that eruptive public space as a diagnostician of classifications, especially those commonly related to the genre of taxons we have learned to classify as "religion"? Social theorist Russell T. McCutcheon has said that such a "shift ... depends upon a rigorous self-consciousness concerning the ease of slipping in and out of the commonsense model even when we claim to be doing something different, something, for lack of a better word, scholarly" (McCutcheon 2017, p. 139). Might there be a place for that in the midst of this public health crisis?

In this working paper, I narrate how the courtesy vehicle driver's comments on the medical resilience of Hebrews has helped me to recognize one racial genealogy—or perhaps, pathology - at work in the time of COVID. Taking a Smithian approach to categories and comparison (Altman 2019), I historicize three conceptual bellwethers for reconsidering the driver's statement.

1. Given the term's use in the Bible and biblical studies, "Hebrew" is better understood as a second-order category rather than a first-order native term. The use of the term is relational, and its meaning cannot simply be assumed by the scholar.

2. Identifying oneself with the "Hebrews" is an identificatory act, the affective and discursive politics of which the scholar can exhume. In particular, "Hebrews" has a racial history in the valuation of bodies on the grounds of origins. In the context of this larger inquiry, this is evident in 19th century debates on "race religion", as well as the ethnogenetic claims of 20th century U.S. religio-racial formations, such as, but not limited to, a broad designation of groups that identify with and/or as "Black Hebrews".

3. As my word play with the consonant homophone "hubris" alludes, scholars should acknowledge the ease with which labels can define reality. Just as we can take greater care with what we make of uses of "Hebrew" and "Hebrews", we can employ comparison to highlight the social ramifications of other essentialist identity claims. In the case of the current public health crisis, we can complicate the ease with which etiological interpretations of "Tuskegee" oversimplify Black people's medical concerns and presumed vaccine hesitancy.

The three points outlined above are the kind of dynamic, enveloping histories that I could have considered with the driver of the courtesy vehicle. And by playing the fool (a la 
Patton), scholars can learn from my malpractice, and deconstruct identifications in a way that brings conscientiousness to the processes by which people come to classify themselves and each other. For such a time as this, I submit diagnostics as a possible model for the public scholar of religion.

\section{Defining "Hebrew"}

Depending on how one chooses to interpret the situation, I betrayed my training as soon as I succumbed to the temptation that the driver was the only one fabricating an image of Hebrew identity. I ceded the role of scholar as soon as I privileged my presumed grasp of origins over the driver's, all the while ignorant of our mutual and competing claims.

I am reminded here of the common classroom occurrence in which a student will ask me about my religion. Even after a discussion of scholarly distance, a student will say, "Okay, I get it, but what are you?". My response is to make an object lesson of their question by reminding them that, "I could tell you that I am a Christian, but you know that that answer tells you practically nothing". Vaia Touna explains why nicely in her provocatively titled monograph, Fabrications of the Greek Past: Religion, Tradition, and the Making of Modern Identities:

"“Identities" do not have an origin that can be located along a linear line that moves unchanged over time or space. Neither are identities public manifestations of internal psychic ontologies. On the contrary, ... [they are] the result of a variety of always present contingencies which, in turn, result in an imposition of a variety of "identity" claims through multidimensional processes by means of a cluster of discursive (i.e., linguistic, behavioral, and symbolic) practices". (Touna 2017, pp. 19-20)

Identity exists in the interstices of social actors and cultural histories. As Smith demonstrated in his lexical analysis of the term "religion", dictionaries are archives of social formation. In chronicling the affixing of meaning to words, they are a snapshot of a habitus' morphology. Thus, "religion" is not without definition. In fact, Smith qualifies there have been numerous definitions, and the rub is that they all radiate from attempts to make sense of one anthropology in light of another (Smith [1998] 2004, pp. 193-94).

"Hebrew", similarly, is a fascinating case study in so far as it has a long history of inflections, the diversity of which should trigger our awareness about the politics which Touna writes. The root concept of "Hebrew" is an unstable taxon, and the driver's signification is but one example of the politics in its orbit. By understanding its various recursions, we can prepare ourselves to later appreciate the nuances of particular ones.

Were I to have heeded Touna's admonition, then I would have been better prepared to see the driver's presumptions to be at least as contrived as the cohesive portrait of Hebrew Identity that even biblical scholars at times adopt. The historian of religion and biblical scholar that I am, my instantaneous dismissal of the driver's use of the term "Hebrew" revolved around, of all things, the rudiments of philology. There is nothing intrinsically wrong with philology, but if we do not resist the impulses of anachronism, then our lexical odyssey becomes an exercise in interpretive vanity, confirming in the past what we seek to realize in the present.

One way to begin to take care is by eschewing the privileging of one synchronic definition for acknowledgment of the diachronic projection of meaning that is in fact how we make sense of anything and everything. Let us pause to consider a recent example of the "plasticity" of the racial term (Smith 2021) "Hebrew", as studied in Benjamin Harshav's (1993) Language in a Time of Revolution, a history of the Hebrew language's role in the development of the state of Israel.

In the early 1900s, emigrants in the two socialist Zionist agriculture parties made use of "Hebrew" to turn Eretz-Israel into the homeland they desired. One group, "Ha-Poel Ha-Tsayir" (The Young Worker Party), had the following slogan: "Our world stands on three things: on Hebrew land, on Hebrew work, and on the Hebrew language" (emphasis Harshav's). As well, a young David Ben-Gurion, a member of "The Party of Hebrew 
Social-Democratic Workers in Eretz-Israel Poaley-Tsiyon" ("Workers of Zion”), relished in the supposed recovery of Hebrew identity in a 1906 letter he wrote to his father in Poland.

"The Hebrew Renaissance, here it is! Hebrew signs on every store. Hebrew speech in the streets, stores, and restaurants, the bus of revival! No. Here you cannot doubt. You cannot disbelieve [ ... ] Here is a Hebrew boy reading with assurance on a galloping donkey, a Hebrew girl, eight years old, rides on a donkey loaded with freights-These are visions of revival!" (Ben-Gurion [1947] 1972, p. 75)

"Hebrew", Harshav summarizes, was a label for the whole revolutionary package, as opposed to the nature of the Diaspora Jew: " ... not just a language but an omnibus positive label for a new kind of Jewish existence" (Harshav 1993, p. 136). As we will see later, the label finds purchase for a number of communities seeking to validate their existence.

The facility of the modern Hebrew language for this kind of fabrication should not be overlooked in biblical studies. Beth LaRocca-Pitts cautions biblical studies teachers with a cautionary tale from Levantine archaeology, where "ancient [Hebrew] words may be borrowed by modern speakers without very careful definition governing that borrowing" (LaRocca-Pitts 2003, p. 58).

Her example of choice is the biblical phrase, "bāma" or "high place". Contemporary archaeological sites will boast, in Modern Hebrew, to have a "high place", but this becomes an empty signifier for everything from a small shrine, to a conspicuous stone within an enclosure, to an open field with a statue possibly cultic in nature. As LaRocca-Pitts writes about this particular anachronism:

"Why is this problematic? In the Bible large shrines were called temples (bayit), and small shrines were called bāmôt. Why shouldn't Modern Hebrew speakers use the term $b \bar{a} m \hat{a}$ to refer to a small shrine? The problem is one of perception. This use of a biblical term gives the impression that archaeologists know what biblical bāmôt looked like. It gives the impression that all of the installations that are today being called bāmôt would have been so called in ancient times. This is something we cannot know". (LaRocca-Pitts 2003, p. 58)

Indubitably, philology can be a helpful tool for understanding the history, morphology, and literature of past language users (Sanders 2009; Vayntrub 2021; Gallagher 2012). However, we should be wary of a philology that becomes the colorful dreamscape of a past painted by present scholars' seeking to lucidly address their concerns.

Historiography is always abstraction. However illuminating it may be, it is an enterprise that loses its brilliance when accompanied by the momentum of interpretive authority and practical application. It also breeds the temptation to memorialize certain stones instead of the scholarly task of interrogatively leaving no stone unturned, a hypocrisy I see as having happened on my part in the courtesy vehicle regarding the term "Hebrew".

Just as the courtesy driver was full of conviction, I saw myself as knowing enough about the history of Hebrew identity so as to be suited to compare-if not evaluate-his claims against the historical record. My mistake lay in the presupposition that there is some thing called Hebrew identity that can be mastered and known, dry bones that I could make talk.

Now here I am no more denying the existence that Hebrew identity exists any more than Smith argued that religion does not exist outside of the scholar's study. Like Smith noted about religion, I am arguing that with each use, the term "Hebrew" is construed from an amalgam of assumptions and analogies that congeal into a proxy to be deployed with greater ease by users again and again. But precedent is not a luxury afforded us, and we fail as scholars wherever we choose to no longer take ownership of our shorthands. Were I to return to the courtesy vehicle, I might quietly recount-if only to humble myself-the fraught grounds upon which a single consistent Hebrew identity could be unearthed from the Bible. 
I would recall that at least in the Tanakh, "Hebrew" is not a term of self-description as much as it is a relational designation. "Hebrew" (Hebr. Ebrit) functions as the ethnic label for a West Asian people group associated with Abram (identified as a Hebrew in Genesis 14:13), Joseph (e.g., Genesis 37-50), Moses and the enslaved people he liberated from Egypt (Exodus), and related devotees of the Lord. The term may come from the sons of Eber (cf. Hebrew Eber) mentioned in the Table of Nations (Genesis 10:21), but even this etymology highlights an inter-group aspect (Waterhouse 2001, pp. 41-42).

It is almost always used in connection with etic entanglements, such as the Egyptians (e.g., Exodus 1:11-22) or Philistines (e.g., 1 Samuel 13-14). Where biblical texts relay emic uses, it is in the context of contests with another ethnic group. For example, Jonah calls himself a Hebrew when asked, "What is your country and of what people are you?" (Jonah 1:8-9 NRSV). The LORD has Moses (and sometimes Aaron) speaking to Pharaoh on behalf of "the god of the Hebrews" (Exodus 10:3). Saul equates the Israelites with the Hebrews (1 Samuel 11:15), trumpeting, "Let the Hebrews hear!", though this is after the defeat of the Philistine garrison at Geba (1 Samuel 13:3 NRSV). Likewise Jeremiah calls King Zedekiah on behalf of the "LORD, the God of Israel" (Jeremiah 34:2 NRSV) to release the Hebrews so that "no one should hold a Judean in slavery" (Jeremiah 34:9 NRSV). Here again, the raison d'être for this "word" is social contest, "when King Nebuchadnezzar of Babylon and all his army and all the kingdoms of the earth and all the peoples under his dominion were fighting against Jerusalem and all its cities" (Jeremiah 34:1 NRSV). This is to say that in the Tanakh, we see "Hebrew" as a marker of difference in painting intermural group activity.

Furthermore, in the Tanakh, "Hebrew" lacks the valence of self-importance or ethnic supremacy. That is more indicative of the tradition of the Apostle Paul, "a Hebrew born of Hebrews" (Gk. Hebraios, Philippians 3:5) who will not cower to those who would see their own Israelite heritage as grounds to dismiss him or his Gentile mission. In the Acts of the Apostles, Paul speaks "Hebraidi" (the language of the Hebrews, cf. Aramaic) to connect with his people and to direct them toward his agenda (e.g., 21:40 26:14). Whatever gain Paul receives from his command over "Hebrew", be it from those claiming covenantal membership on ethnic grounds or otherwise, the consonance of Hebrew ethnicity and Hebrew language is a byproduct of classificatory concerns that lay beyond the veil of Second Temple ethnic homogeneity.

Angel Sáenz-Badillos provides a salient reminder that the fused ethnic and linguistic designation known to us in modernity is more of a Hellenistic formation than one "originary" to the laden anachronism that is the "Hebrew Bible". The language of the Tanakh internally is expressed either as "the language of the Judeans" (Hebr. Yehudit, contra the Aramaic of the dominant Neo-Assyrians 2 Kings 18:26) or the language of Canaan (Hebr. Sephat Kanaan, in contrast to the languages of the Egyptians and Neo-Assyrians Isaiah 19:18) (Sáenz-Badillos 1996, pp. 1-2).

The layering of these designations with the cultic association of "Hebrew" (whatever interpreters take that to mean) is belated. Though the vast history of the forms this takes in early Christianity and Second Temple Judaism is beyond the scope and interest of this paper, the permutations thus far described position us to think about "Hebrew identifications" as what biblical scholar Denise Kimbrell Buell calls a program of "ethnic reasoning". As she expertly demonstrates in her study of race in the late antique Mediterranean, the past is a canvas for working out matters of authority, history, and communal logics (Buell 2005, pp. 25-34). This is part of what makes scholarly discussion of Hebrew so difficult.

"By portraying a people as continuous over time, historical ethnographies or mythic tales make ethnicity or race seem fixed. At the same time, historical accounts often display the fluidity of ethnicity/race by suggesting, for example, that one people can be transformed into another (that Romans emerged from the Greeks, Christians from Jews) or that different peoples can emerge from a common ancestor (Jews and Spartans from Abraham, Ilians and Romans from Aeneas)". (Buell 2005, p. 64) 
What we witness in kind with "Hebrew" is that it is becoming a language of a people, and a people with a language for accessing the means of power in theological terms. "Hebrew" is not just a language or an adjective affixed to a scripture. In Vincent L. Wimbush's words, it is a "scripturalectic" for narrating and legislating the strivings of peoples-among them Israelites, Judeans, Jews, Christians, and, as we will later discuss, Black Hebrews (Wimbush 2017, pp. 5-6).

As we are trained to expect, the origins discourse is an active site in the term's interpretive history. For instance, in Against Apion I.14-16, Josephus contends that his ancestors are in fact the same shepherd people that the Egyptian historian Manetho identifies as the "Hyskos", a line of foreigners who ruled Egypt during the Second Intermediate Period, and mentioned in Hellenistic Egyptian historiography. Though contemporary historians doubt the veracity of the connection, its logic makes sense in a work designed to establish the historical pedigree of his people in the face of Apion's etiologically polemical claims about the Jews (Dillery 2003). To be fair, Josephus does not use the term "Hebrew" in his discussion, but the appeal to origins is telling, if only because of the fodder it gives for later biblical scholars' identification of the Hebrews with other better historicized Semitic attestations, such as the hypothesized Akkadian cognate, "Habiru/apiru".

Mentioned in the archive from et-Amarna/Akhenaten, this 13c. BCE Canaanite group was a vassal to Egypt. The name is an Akkadian term which, depending on how one deciphers the cuneiform, means "to pass, cross, or traverse" (cf. Habiru, denoting foreignness) or "dust, or clay" (cf. Apiru, perhaps connoting low social status) (Lemeche 1992a, 1992b). Its Sumerian translation, SA.GAZ, suggests a denigratory character like "lawlessness" to the group ascribed (Na'aman 1986; Waterhouse 2001, pp. 31-32). Not unlike Josephus' work in Against Apion, the arguments for this relationship originate "Hebrew" in accounts of which scholars think they have better-if not more of a handle. For all the methodological sophistication on display, the arguments reach for hypothetical external markers rather than holding space with the limited self-descriptions available to us. We see the implications of this in an intriguing exchange during the Chuen King Lecture Series at The Chinese University of Hong Kong (CUHK).

In 2001, Jack M. Sasson spoke at CUHK on the very question of Hebrew origins in light of historiography, history, and religion in Ancient Israel (Sasson 2002). A distinguished biblical scholar, his remarks were an expert show of explanatory acumen and facility with sources, covering - if not, elaborating on many of the etymologies and characterizations highlighted in this essay. But what stands out to me about the published version of the lecture series are the responses from working Chinese scholars testing Sasson's ideas against a variety of interested communities - most specifically, academic historical-critics and practicing Christians in Hong Kong. In response to Sasson's lecture "On Hebrew History", Craig Y. S. Ho took a moment to reiterate the situatedness of the origins project.

"All histories were written in retrospect when past events were selected and interpreted from a certain perspective. Such a perspective is a framework of meaning that relates a certain set of individual events and assigns cause-effect sequences to them. Such a framework of meaning is actually the interpretation imposed by the historian upon the events. Interpretations are not derivable from meaningless events; instead they come from the mind of the historian". (Ho 2002, pp. 70-71)

I would put a finer point on Ho's critique by mentioning that Sasson spends little to no time questioning the problematics of positing a cohesive portrait of Hebrew. Admirably, Sasson seems to take the challenge in stride, likening biblical studies to the Tower of Babel, a situation where the multiplication of our scholarly forbearers' "interpretive tools" assured that "their descendants-historians, theologians, philosophers, archaeologists, and, for better or worse, political leaders-can never resist searching for solutions to issues raised in the sacred writings of the Hebrews ..." (Sasson 2002, pp. 131-32).

Sasson makes a crucial point deserving of greater attention, one that prompts me to ask what and who make "Hebrew" so important. The matter of "Hebrew" and origins is 
not at all settled for scholars. And any search that forgets itself in exchange for the blissful ignorance of remembrance-let alone discovery-will struggle to observe the powers of interpretation.

In an edition of the language and culture column called "On Roots", Ha Aretz anthropologist Jeremy Benstein takes up the etymology of Hebrew by looking at the root word "eber", again meaning something like "across", "pass", or "cross" (Benstein 2013). Presumably, its appearance in the term "Hebrew" stems from the people's journey across the river Euphrates, but, again, this is an etiology based on another group needing to situate from where these people came. In terms of an agential use of the term, "Hebrew" and "eber" have come to mean quite a lot. Beyond what we have discussed, Benstein discusses how the invention or rediscovery of a modern Hebrew language has seen some intriguing permutations of root word-from passing a test (Hebr. "avar"), to transit camps for Israel-bound immigrants (Hebr. "Ma'abarot"), to ferry or even space shuttle (Hebr. "Ma'abret"). And lest we forget, one who commits a crime is an "Avaryan".

More than the resonance of ancient and modern significations of Hebrew, I am intrigued by Benstein's conclusion about the use of language as a metric of identificatory possibilities.

"Some claim that Israelis don't speak Hebrew, any more than Italians speak Latin. But while the contemporary lingo is indeed far from the classical tongue-and getting farther-there is a continuous historical memory, and dynamism and global influences, even if they augur great changes, are the life blood of any living language. Which 'ivrit surely is!" (Benstein 2013)

I agree with him about the dynamism of people and language. That is, studying the dynamics of identity claims are not well measured in the units of a lexicon-that is, synchronic definition. Benstein's diachronicity is better equipped for the task. But what amazes me is the manner in which even his conversation of history and philology literally turns to the tempting metaphor of sanguinity. Yet knowing what we know-or maybe better said, unlearning what we have learned - neither sky (nor space, as it were) are ever the limit in defining "Hebrew". And when we play the fool, we begin to notice how communities manage its definition for their own purposes. In the next section, we will explore some of the scholars and Hebrews who have tried this for themselves.

\section{Identifying "Hebrews"}

I suspect that my charged reaction to the driver's appeal to Hebrew identity was as much a product of our differing historical sensibilities as it was his racial categorization of me. I am familiar with arguments about "ontological blackness" (Anderson 1995; Cone [1969] 2019) and how the socio-cultural politics of race can help to account not just for understanding modern person's presumed constitutions, but existential proclamations. In this pandemic moment, we might consider how the phrase "Black Lives Matter" has been amplified and how wider publics are growing increasingly aware of its layers (Reinhartz 2017, p. 203; Reinhartz 2020; Newton 2020).

And yet, the scholarly distance I learned to manufacture during my training in religious studies and anthropology would not permit me to see that lone declaration- "We're Hebrews, you know?" - as anything but strange. The idea that the pandemic would somehow pass over us as a result of our being Hebrews made our crossing of paths particularly eruptive. The dangerous stakes of his identity claim triggered my hermeneutic of suspicion, and formed a chasm between us in spite of our various proximities.

To Patton's point, I do not think that the public good requires my capitulation to the gentleman's truth-claim. But queries (over inquisition) on the matter of "Hebrew" identity could have helped me devise a more measured response. Instead of saying that the driver's understanding of Hebrew identity simply cannot be, I should have been asking him about how and why the Hebrews will be spared, and what led him to identify himself (and me) as one of the Hebrews. This already shifts the polarity of the public space from eruption to entropy, the sort of deconstructive predicament where scholarly work is better suited. 
Even for those who would take umbrage at my assertion, and advocate for a more constructive approach, the foolishness to which I have gestured lays groundwork for a desirable learning moment for the parties concerned. This is the case as long as the question is delimited to "anthropocentric examination" rather than the evaluative discussions that an "addiction to origins", theological or otherwise, ultimately reifies (Braun 2020, pp. 17-21). Having been too wise to inquire further about the driver's conscription of Hebrews, I missed a research opportunity and failed to do my job.

We would do well to review the way race has colored some significations of Hebrew identity so that we understand the power of categories. On this, I think biblical scholar David G. Horrell models the ethos we should take in our redescription of race. He calls us to resist hyper-confidence in our own social-scientific rubrics.

"However it is important not to regard such lists of characteristics as the basis for a kind of tick-box exercise through which we can determine whether such and such a particular group is or is not an ethnic group. It is vital to attend carefully to the particular ways in which appeal is made to any one of the characteristics in particular texts, whether in modern or ancient contexts". (Horrell 2020, p. 89)

Again, every evocation of "the Hebrews" delimits who someone is and is not on some set of criteria for further elaboration, even when the criteria goes undisclosed. What I continue to submit here is that scholars of religion have a history of operating as an interested party in adjudicating who properly befits the category Hebrew based on knowledge they have claimed to master. Wise foolishness would have us be more curious about the history of Hebrew identity in the study of religion. As I have come to realize, the classificatory rubrics of scholars and the courtesy vehicle driver may have more to do with each other than I first thought, and that connection revolves around the co-constitutive histories of "religion" and "race" (Nye 2019, p. 43) as second-order categories.

Subtending contemporary conversations about the usefulness of religion as an analytical category is the debate of what and who the scholar is trying to classify. As J. Z. Smith advances, this was at stake in the late nineteenth century Sanskritist W. D. Whitney's binary rubric of "founded religions" versus "race religions" (Smith [1998] 2004, p. 189). Founded religions encapsulate the innovations of a compelling figure, the devotion of followers, and a community's drive toward an absolute truth and power that ultimately transcend socio-geographic boundaries. "Race religion" bracketed the accidents of a religion (e.g., fetishism and superstition) as they were intimately linked, if not intrinsically limited, to separate people groups with little interest beyond their sovereign boundaries (Whitney 1881, pp. 449-52). Race religions were a local phenomenon; founded religions, a global one. And that contrived distinction mattered a great deal.

What was being teased out among scholars like Whitney and his rival, philologist Friedrich Max Müller, was how notions of "race", "blood", "lineage", "descent", and "grammar" related to ethnological difference (Masuzawa 2005, p. 239). Müller was optimistic about languages (and the sacred books that exemplified their use) as keystones in his construction of naturalist explanations of socio-historical diffusion. People groups were, by and large, synonymous with language groups; they and their evolution could be mapped as such. Whitney, however, was suspicious of such claims. He understood the politics of language to be but one element of culture, and that an adequate social history would require far more than philological data (Valone 1996, pp. 129-30). By point of contrast, historian David Valone writes the semiotician Ferdinand De Sassure tried to avoid discussions of race and religion altogether in his advancement of a pure study of language, a departure that highlights the position race science assumed in the intellectualism of the era (Valone 1996, p. 131).

The recent metacritical incursion in the academic study of religion has underscored that the philologically-rooted comparative world religions project of the 19th century (Masuzawa 2005, pp. 234-54) in general, and the Romantic project of biblical studies, in particular, warrant closer attention. About the latter, Robyn Walsh refuses to let scholars forget that "the Geist of the Hebrew Scriptures were myth about myth" rather than the 
encapsulation of the antique reality of our intellectual dreams (Walsh 2021, p. 49). And though scholars have shown great deftness in examining complexities around the related term "Jew" (Magid and Reed 2017; Milligan 2019, pp. 6-13), this work needs to similarly be done with "Hebrew" beyond the presuppositions of race religion, where knowledge of the "Semitic" is hermetically and hermeneutically sealed for scholarly convenience.

Race religion does not seem to account for Hebrew culture itself being a fluid construction that, like any other, becomes meaningful in relation to its utility, especially in negotiating new social challenges. Failing to disrupt this comes at the expense of our appreciation of the nimble identifications that put the term in our field of vision in the first place. Acknowledging this in the courtesy vehicle would have been important because the ethnic reasoning of race religion contributes to the situation that prompted what Judith Weisenfeld has called "religio-racial" social formations, of which the driver's statement on Hebrew identity might be predicated.

For Weisenfeld, the designation "religio-racial" is more than an acknowledgment of the pervasive impact of race on modern social formation. It is an observation of "a set of early twentieth-century black people whose members believed that understanding black people's true racial history and identity revealed their correct and divinely ordained religious orientation" (Weisenfeld 2016, pp. 10-11). When one considers that race religion concretized a metric of orthodoxy that necessitated categories of distance like "sects", "cults", and "new religious movements", then religio-racial movements emerge as a way to highlight social organizations whose members felt that religion and race together presented an overwhelming discourse that had to be addressed in equal and opposite terms (Weisenfeld 2016, pp. 12-13; Goodwin 2021).

U.S. "religio-racial movements" are underside significations of race religion, and we see their importance at sites of classificatory conflict. Initiatives like the Federal Bureau of Investigation's COINTELPRO operation maligned Black nationalist groups (of which Black churches and other religio-racial communities were often classified) through exoticizing depictions, relentless surveillance, and judicatory entrapment (Donner 1980, pp. 204-40; Weitzman 2013, p. 962; Martin 2018b).

This culminated in pictures of religio-racial groups as antithetical to the aims of "the Christian Century" (Johnson 2015, pp. 312-62; Martin 2018a), the increasingly prominent U.S. White-Christian ideal that American Christians would make good on the great commission of Matthew 28:18-20, and proclaim the salvific name of to the very ends of the earth in the 20th century (Toulouse 2000, p. 80; The Christian Century 2000, p. 77). As historian Susan Curtis put it, "Worldwide social salvation would come at the hands of the United States ... A nation, not a religion, dedicated to social welfare and social reform would pave the way for self-realization" (Curtis 1991, p. 193).

Here, we should note that the magazine editors who coined the phrase "Christian Century" in 1899 worked from a headquarters in Chicago, a bellwether city where a different kind of Great War was reaching fever pitch. Five years prior, Chicago had hosted the World's Fair: Columbian Exposition (a figurative ground zero for the world religions paradigm). Additionally, mainline White Protestants found themselves competing for jobs with a wave of immigration and Black laborers from "The Great Migration" (Wilkerson 2010, pp. 415-20). In 1908, the Federal Council of Churches formed as White Protestant buttressed against the social and economic woes in urban centers-problems often attributed to these "others" (Curtis 1991, pp. 6-15, 142-46). Meanwhile, the resurgence of the Ku Klux Klan (and similar groups) offered vigilante means of securing the status quo (Blum and Harvey 2012, pp. 159-69; Baker 2011, pp. 169-97). And not to be missed is how in cities like Chicago, U.S. White-Christian salvation all but left Black people behind.

Historian Milton C. Sernett documents a bold example of the consequences of white flight in his discussion of Olivet Baptist Church, a Black institution fending for itself in the same city at the same time.

"As white congregations and synagogues abandoned the South Side and relocated to escape the expanding Black Belt, Olivet's leadership saw an opportunity 
to obtain more adequate facilities. First Baptist, the oldest white Baptist church in Chicago, saw its membership decline to 403 by 1918. White families sold their homes for whatever they could get. "No eloquent preaching, no social service", a report stated in 1918, "could save a church in a community that was nearly loo per cent Negro" or long survive when "Negroes are steadily pushing down the alleys southward with their carts of furniture"'". (Sernett 1977, p. 157)

The shrewd leadership of Olivet Baptist Church worked out a salvation apart from white people and white Christians. Religio-racial communities, in learning that they were neither Christian nor white enough to be at home in America, fled double jeopardy in even starker ways. The present literature on this era makes this abundantly clear.

Historians of American Religion working out of the New Materialism have countered portraits of aberration with explanations of religio-racial social negotiation. In these studies, the Nation of Islam's dietary and fitness regimens, for instance, fortified the body and soul of members (Curtis 2002, pp. 171-74). The homeopathic toiletry line of the Moorish Science Temple of America and their Aliite garb tended to bodies marked and scarred by the ascetic efforts required to fit in a habitus (Clark 2013, p. 33; Dew 2019, p. 29). For scholars of "lived religion", these idiosyncrasies have become important finding aids in the archive of the pride, dignity, and respect cultivated by these groups. For the discursively-oriented scholar, they signify people's grasp for what historian Spencer Dew calls "relational sovereignty", moves to exude and receive political validation in the "ever-shifting relations" of social groups (Dew 2019, p. 47).

Though I do not know the specifics of the driver's religio-racial identification with the Hebrews, his conviction that it would save him from the pandemic reflects an affective connection with what the term represents. We need not maintain the actuality of Hebrew identity to recognize the affects "elicited" and "activated" (Bain-Selbo 2019). But, at least to me, there seems to be an embodiment conditioned through engagement with the semantic domain of "Hebrew" that is of importance. Being a Hebrew is an epistemological statement about who one is not, who one is, and how the world should thus be engaged. Thinking with Donovan Schaefer, we might redescribe the driver's identification with the Hebrews in terms of "bodies mobilized by the unruly matrix of dense affects working their way through us", specifically in relation to religion and race (Schaefer 2019, p. 21). And it is in historicizing these moves, as we did in the biblical cases in the previous section, we may yet register some of the nuances in the driver's signification of the identification.

Throughout the long twentieth century, many groups in the US have claimed a Black Hebrew religio-racial identity. The relationship between these groups and Judaism is a matter of scholarly debate, but African American studies scholar Andre E. Key's navigates the delineations with this measured typology:

"While there are several orientations of Black Hebrew religion, there is nevertheless an underlying unity to Black Hebrew belief-namely, that African Americans are the literal descendants of the biblical Israelites, who, as result of their divine disobedience, experience ethnic suffering. From that single assumption has emerged a multiplicity of ways to articulate what it means to be a Black person who is a Hebrew living in the modern Western world". (Key 2014a, p. 63)

The history of religions helps us sharpen this sense of how "modern Western" life has been negotiated, as well as the possibilities Hebrew affiliation has provided. Insofar as Jewishness is often read in the US (problematically) as White or white-passing (Milligan 2019, pp. 95, 98-100), "Hebrew" and "Israelite" identification manufactures distance from Eurocentrism, Christocentrism, and the problems presumed to extend from them.

Speaking of the Congregation of Commandment Keepers, Sylvester A. Johnson highlights how "[r]eading scriptures in Hebrew, following a kosher diet, wearing distinctive clothing - these signifying practices were a vital means of representing racial Blackness as distinctive, pre-American, religious, and honorable" (Johnson 2015, p. 297). This "ethno- 
genesis", as Johnson argues, becomes a central strategy for critiquing the radical equation of civilization with Whiteness and/or Christianity on the basis of origins.

"This humanistic strategy of mapping religion resulted from European colonialism and was induced by the myriad colonial contacts that compelled Enlightenment thinkers to view differently what was previously regarded as Christian religious truth. Eventually, the taxonomic imperative - the drive to classify and locate along a hierarchical "order of things"-induced an ironic turn in the Christian knowledge of religion that created, by contrast, a humanistic knowledge of religion". (Johnson 2015, p. 302)

To this point, Key contends that the label "Black Jew" is most commonly used as an ethnic/racial designation, and is used by those seeking to distinguish themselves from "white Jews" or "Ashkenazi Jews" (Key 2014a, pp. 41-42). And even then, this label is less prominent than "Hebrew", "Israelite", or "Hebrew Israelite", which appears to be the more preferred identifier in the historical and ethnographic data. (Nota bene: The driver did not add the modifier "Black".)

In my reading of Jacob S. Dorman's study of New York Black Israelite "bricolage", I was struck by the ethnogenesis being "discovered" in the unfurling of testimonies, orbiting the term "Hebrew" in members' testimonies (Dorman 2007). Describing his transition from a checkered identification with Christianity to his increased affirmation as an Israelite, Rabbi Arthur Matthew said, "I got tired of Christianity, of going from church to church". "Got the spirit it wasn't right. Just found this by myself because I wanted Hebrew. Like I was reaching out and discovered this". (Dorman 2007, p. 69). This sentiment resonated with a 24 year-old woman who had become a follower of Matthew in 1927 after hearing his street-preaching. She had been a housekeeper for a White Jewish households in the Bronx, where she saw up-close a stark contrast in the impoverished conditions facing many Black people. Matthew's teaching about the prophets as being, in actuality, Black helped her find where she belongs. "I did not join the Hebrew faith-I returned" (Dorman 2007, pp. 69-70).

Whether the driver understood himself as a Hebrew in the same manner as Matthew or others identified as Black Hebrews is both unclear to me and now a more complicated question than I would have entertained in the moment. The gentleman never named any other Hebrews beyond himself, me, and the broader group to whom we are both a part. And as we have previously discussed, "Hebrew" is commonplace in the history of, to borrow the title from Anthony B. Pinn's treatise, Terror and Triumph: The Nature of Black Religion (Pinn 2003). It has utility in signifying one's way through theodicy (Pinn 2017). Part of what is fascinating about the driver's particular signification is that he saw his identity as playing a protective, salvific, or liberatory role in the face of this particular panacea.

In Key's study of Black Hebrews, those who identify as such usually see present difficulty and theodicy as a necessary pre-text to repent from their "mis-identity" and undergo "gnosiological conversion" (Key 2014b, esp. 271, 282-85). Drawing upon his ethnographic research, he poignantly notes that one distinction between the Black Hebrews he has studied and other exemplary groups in Black Religion (e.g., Black Christians, Black Muslims) is at the level of arrogated ontology. The former makes an existentially metaphoric identification with Hebrews rather than the latter's similized affinity. "They are not like the children of Israel; they are the children of Israel. As such, their worldview operates along a historical continuum that places events of the biblical past immediately next to the lived experiences of African Americans in the twenty-first century" (Key 2014b, p. 271). The real-time pathos provides an occasion to double-down on the true knowledge of self. Thus, the presence of suffering is, in a way, expected rather than eschewed.

The driver's "Hebrewness" operates differently. "Mis-identity", "gnosiological conversion", and "ethnogenesis" remain applicable in redescribing his signification. But if the Black Hebrews discussed above live in the Deuteronomistic melodrama that we associate with the whole of the Tanakh, the driver seems to be more fixated on the episode of the 
Pesach. The pandemic is not a punishment for Black people. COVID-19 will pass over Black people because of their Hebrewness.

It is from this broader context that I am reminded that though generalizations are part and parcel to what we as scholars do, we would do well to treat identifications and diagnoses on a case by case basis. In a 2018 essay in Culture and Religion, Sierra Lawson and Steven Ramey deconstructed a popular nursing textbook's use of the world religions paradigm to develop culturally-sensitive health regimens that were anything but (Lawson and Ramey 2018). They effectively show that nuances can have consequence.

As a scholar, I gather that Hebrewness afforded the courtesy vehicle driver a psychosomatic knowledge about where he comes from, one that leaves him unphased by the onset of the pandemic. He seems to have a racialized sight to know his kin. And as much as that pronouncement may strike one strange, as it did me, such a religio-racial formation, in some ways, mirrors the conditions that normalized "race" and "religion" in the first place.

The lines between birthright, academic credential, and knowledge are murky at best. And rather than losing heart, scholars should roll up their sleeves and get to the work of asking good questions and assisting with careful examination of our historical moment, when attention to how we move around each other is paramount.

\section{Identifying "Hubris" in Comparison}

Scholars are not unlike the African bishop Tertullian asking, "What indeed does Athens have to do with Jerusalem?" We can and should raise an eye at the ethnic reasoning of his Christocentric supersessionism. Nevertheless, comparison is what scholars do. As Smith ends his famous essay on Judaism, "'How am I to apply what the one thing shows me to the case of two things?" The possibility of the study of religion depends on its answer" (Smith 1982, p. 35). So too does the possibility of public scholarship.

In the course of my thought experiment, I have explored these possibilities by returning to the eruptive public space that is the courtesy vehicle. Hearing the driver's statement, "You know that won't get us, right? We're Hebrews, you know", I came to wonder what Hebrew Identity and Blackness have to do with the COVID-19 pandemic. Where I had once quickly thought to myself "nothing" on account of my scholarly training, that same training has led me to reconsider my position. To summarize:

(1) "Hebrew" is a term like any other, one that must be signified by a community for it to be meaningful. A cursory survey of ancient and modern significations reveals a plethora of ways the term has become a category to mark social difference between groups. This variety should prompt us to think of Hebrew identity as a classificatory event rather than a categorical certainty.

(2) Identifying "Hebrews" is a political act. In some instances, it is an act of cultural management and ideological containment, as we saw with uses of the race religion rubric. That said, identifying with or as Hebrews can be an act of social formation and negotiation, as is often the case with religio-racial movements like the Black Hebrews. Analysis of the discourse and affects that inform these identifications requires a concerted effort-much more than my initial flippancy (mis)represented.

By playing the wise fool, I have come to realize how, in comparison, hubris dwells. I do not begrudge the sort of epistemological self-knowledge that is part and parcel to the modern predicament. But that kind of confidence is not warranted in scholarship, for we know in practice how Müller's dictum "he who knows one, knows none" can morph into a scenario where the scholar de facto "knows more", "knows all", or has "nothing to learn". Josephus's Hellenizing commentary on the hubris of the Ancient Jews bears this out in suspicious and suggestive ways.

Josephus took up Tertullian's question on comparison a century prior. In his Antiquities, he contextualizes the Iudaiois of the Septuagint (that is, the Hebrew Scriptures rendered in Koine Greek) within the historiographic values, tropes, and conventions of Hellenism, thus, translating the Iudaois into an ethne worthy of regard. For instance, Josephus frames Israel as a laudable people with a law (i.e., The Torah) that would guide them straight and true 
were it not for the people's penchant for hubris. Classicist Danie B. Levine's intrigue in this theme is well-founded. As he details, the Greek term appears in the text of the Septuagint twice (Genesis 49:4 and Leviticus 26:19), and yet, Josephus's paraphrastic excursus on the Pentateuch (that is, the five books of Moses in Greek) deploys the term "hubris" 46 times, none of which are in reference to the actual uses of the term in the Septuagint (Levine 1993, p. 51).

Josephus quite literally reads "hubris" into his identification of the people often understood as Hebrews. And in these cases, Levine writes, hubris is not simply a matter of pride or insolence (as Genesis 49:4 and Leviticus 26:19 exhibit). It is a judgment that comes as "the result of excess", especially sexual and financial excess (Levine 1993, p. 79). Josephus uses this to lionize prophets like Joseph and Moses, who eschew hubris, and to critique unflattering moments in the history of the Ioudaioi.

It is in Josephus's layered ethnic comparisons that I think there is a lesson. The privilege he reserves to define and judge a people is something scholars must avoid in our drive for understanding and being understood. Similarly, what I hope to have made clear is that my hubris about Hebrews is an academic malpractice from which we can learn, and perhaps one about which we can teach our publics, bringing us full circle.

Most recently, one instance of identificatory hubris that has caught my attention is the characterization of COVID-19 vaccinations among Black people in the United States. In it, are analogs to what we have seen in treatments of "Hebrew" and "Hebrews". In late 2019 and early 2020, Americans began to give attention to the racial aspects of the pandemic. As National Public Radio correspondent Taylor Sisk put it,

"The pandemic has struck Black communities with a vengeance. Black Americans are twice as likely as white Americans to become infected with COVID-19, three times as likely to be hospitalized with the virus, and more than twice as likely to die from it ... They're also less likely to get vaccinated ... half of Black adults said they probably would not or definitely would not receive a COVID-19 vaccine. Only one in three of the population as a whole said the same". (Sisk 2021)

This phenomenon, widely known as "vaccine hesitancy", is not limited to Black people, but it has been said to disproportionately affect Black people. What I have noticed is that Americans have been less interested in asking why, rather than assuming the answer. That answer has been prematurely distilled into the complicated term, "Tuskegee".

Tuskegee is a town in Eastern Alabama. Its name derives from a Muskogee word "warrior", descriptive of the indigenous people who resided near a creek in the area (similarly, Tuscaloosa bears the name of "the Black Warrior" who was once a chief of that tribe, cf. Muskogee, "loosa", meaning "black"). The town is in a region of Alabama known as the Black Belt. Though some attribute that to the racial population of the area, it derives from the fertile soil that these people and their descendants have worked (Gray 1998, p. 27). Yet, the pseudo-etymology does provide a solid heuristic reminder of the torturous and inspired ways people there have sought to define Black life.

Tuskegee is also known for what is now named Tuskegee University, famously led by the industrious Booker T. Washington, and home to the famed George Washington Carver. Part of Washington's strategy to spread the school's renown involved cultivating ties in North Africa. His idea was that Black people could leverage their farm skills in these hotbeds of colonial and capitalist investment. But such enterprise should not overshadow the subtext of life in places like Tuskegee, a pathos frequently compared to that of the Hebrews.

In 1904, a white entrepreneur and agriculturalist named Leigh Hunt, who would collaborate with Washington on such a plan, was described in the Sudan Times as "a giant who proposes an exodus of the American nig-rs to their Canaan" (Tounsel 2020, p. 33). Following WWII, Tuskegee became famous as a training site for Black U.S. Army Air Force aviators who persevered against enemy air forces and discrimination in the military. Tuskegee was also the birthplace of civil rights activist Rosa Parks, and the site of Gomillion $v$ Lightfoot (1960), one of the major U.S. Supreme Court decisions to inhibit gerrymandering 
(Reverby 2009, p. 132). All this to say, Tuskegee has been known for both slavery and freedom. Hence, it is one among many sites where Black people have been read as Hebrews bound for, and by a matrix of, liberation (Newton 2017).

Tuskegee is also famously remembered for a medical tragedy, but not in the way many think. From 1932-1972, Black men from the area were recruited to participate in the United States Public Health Service Syphilis Study at Tuskegee. The 623 Black men from the region reported to have symptoms of what was euphemistically called "bad blood". The men enrolled were informed that they were part of a longitudinal study about treatment of syphilis. But what they were not told is that the study was designed to examine the long-term effects of syphilis, a malady investigated heavily in the early 20th century and known to be especially prevalent in the Alabama Black Belt.

The deceit was unconscionable. All participants were not only given placebos, but in many cases, local medical practitioners actively refused to treat the men with penicillin, an antibiotic known to be effective against it since 1947. This prescribed and premeditated omission would allow doctors to examine the deleterious effects during observation of live patients and in autopsy (Reverby 2009, pp. 116-34, 151). Outside of rumor, neither participants nor the public knew of the details of the study until a 1972 lawsuit (Gray 1998, pp. 80-99). The federal government did not admit wrongdoing until 1997, when Bill Clinton issued a presidential statement and apologized on behalf of the United States government. The Tuskegee Study is undeniably horrific, and reflection on it rightly informs practices of institutional review, patient's rights, and medical ethics today.

As historian Susan Reverby has masterfully documented, Tuskegee finds renewed relevance during public health crises that disproportionately impact Black people (i.e., the aftermath of Hurricane Katrina, the AIDS epidemic). But the "Tuskegee" mentioned is one of complicated and often inaccurate imaginings. Among the most prominent mythology is that the U.S. government gave Black people syphilis.

"This belief is everywhere: the Internet, the national nightly news, academic papers, and in deeply held beliefs among health professionals and the public. Stories circulated claiming that those injected included black women, prisoners, Tuskegee Institute students, and the Tuskegee Airmen of World War II fame, whose effort was called "The Tuskegee Experiment"”. (Reverby 2009, p. 200)

Though the United States perpetrated a massive act of injustice in the name of science, it is not always the one of which many are thinking. Like Hebrew, "Tuskegee" is not a stalwart fact, but an interpretive move. And as of late, one need not look far to find media coverage that moves from Black vaccine hesitancy to Tuskegee (Huang 2021). By way of comparison, I wonder how a wise fool could complicate the juxtaposition. How is Tuskegee important to the pandemic's effect on Black people from the perspective of a scholar of religion?

Scholars of religion and policy wonks alike know to question origins. Public health scholar Jay Pearson reminds that in addition to the incident at Tuskegee, one could point to stories popularly and personally known in medical malfeasance, "such as Henrietta Lacks and other Black women whose bodies were literally used as living laboratories" (Sisk 2021). Furthermore, we can contextualize the precedent and legacy of this through historical study of disabled people (Rose et al. 2021), enslaved persons (Huang 2021), and colonized peoples (Reverby 2009, pp. 192-95; Paul and Brookes 2015). Such comparison would not trivialize or minimize the significance of Tuskegee as much as position the observer to examine each instance with nuance. As urgent care physician Dr. Robert Drummond posits, "You can't treat if you can't empathize" (Huang 2021). That said, we must be mindful of the terms with which we execute our comparisons, even the empathetic ones.

Just as Horrell warned us of becoming too enchanted with our analytical rubrics, critical comparison gives mind to the limits of analogy. When Joyce Christian and Lillie Head, descendants of participants in the Tuskegee Syphilis Study, were asked about the experiment's relevance to Black vaccine hesitancy, they pushed back against the equation. In an interview with writer Morgan Jenkins, Head said: 
"What I find interesting is that when penicillin became known as the therapy for treating syphilis, those men were denied treatment. I'm having trouble understanding the logic. The men in the study didn't get a vaccine. You are comparing men not getting a vaccine to a vaccine that is available. So how can you compare not having something to the opportunity to have something?" (Jenkins 2021)

Head's observation also highlights the issue of whether Black people have the same access to the vaccine, or if this is a matter of broader racial disparity in health care-in Alabama specifically, and more broadly, the United States (Shapiro and Eltohamy 2021; Shapiro 2021). Even barring the question of access, there is not an intrinsic correlation between knowledge of Tuskegee and Black people's hesitancy to participate in public health efforts. Studies suggest that vaccine hesitancy among Black people has little to do with "Tuskegee", contrary to the public's pridefully guilt-laden essentialist historical image of Black people.

Indeed, knowledge of Tuskegee may account for some indifference or mistrust of public health initiatives among Black people. For example, a study funded by the National Institute of Mental Health learned that "the Tuskegee Syphilis Study is of relatively limited direct relevance to individuals in criminal justice settings who refuse to participate in survey research" (Poythress et al. 2011, p. 827). Overall, "accurate" acquaintance with the Tuskegee Syphilis Study was low, though "accuracy rates were higher among Black non-participants" (Poythress et al. 2011, p. 826). Similarly, a 2011 review of results from the 1999-2000 Tuskegee Legacy Project Questionnaire observed that those persons aware of the Tuskegee Syphilis Study were less willing to participate in biomedical research.

But though Black people were found to be more aware of the Tuskegee Syphilis Study than White and Hispanic people, the reticence of White people who were aware of the study was statistically more pronounced in the aforementioned 2011 review. The researchers hypothesize that this:

“... may reflect the daily cultural reality in the Black community, which has for a long time been accustomed or increased risks for Blacks in many activities. For Whites this type of information (or news) may have been more shocking and at odds with their daily expectations and thus, led to a stronger negative impact on their future decision making". (Katz et al. 2008, p. 1140)

My point is that Black people have a lot of reasons to distrust institutions of medical practice. And those that do not already have enough barriers inhibit them from potential healthcare options. Tuskegee is not a hang-up for Black people because it is a history that has not passed. However, for those for whom Tuskegee and historical instances like it are news, it can potentially feed sentiments like vaccine hesitancy. What is clear is that adopting "Tuskegee" as a shorthand does an injustice in an eruptive public space where clarity and complexity need not be opposed. Hubris comes before the fall. Just as I might have asked the courtesy vehicle driver about his confidence in the preventive effects of his Hebrew identity, scholars might model that curiosity in public.

Dr. Brytney Cobia is a hospitalist at Grandview Medical Center in Birmingham, Alabama who made national news for her candid reflections on the surge of COVID-19 cases due to highly-contagious Delta variant and the state's relatively-low vaccination rates. Speaking about her patients she said:

“They cry. And they tell me they didn't know. They thought it was a hoax. They thought it was political. They thought because they had a certain blood type or a certain skin color they wouldn't get as sick. They thought it was 'just the $\mathrm{flu}^{\prime}$. But they were wrong. And they wish they could go back. But they can't. So they thank me and they go get the vaccine. And I go back to my office, write their death note, and say a small prayer that this loss will save more lives ... "You kind of go into it thinking, 'Okay, I'm not going to feel bad for this person, because they make their own choice ... But then you actually see them, you see 
them face to face, and it really changes your whole perspective, because they're still just a person that thinks that they made the best decision that they could with the information that they have, and all the misinformation that's out there". (Pillon 2021)

At the end of Who Owns Religion?: Scholars and Their Publics in the Late Twentieth Century, Laurie L. Patton provides a list of questions to help scholars reflect on their work as they pursue foolish wisdom in public spaces (Patton 2019, pp. 261-64). I end this working paper in the time of COVID-19 coming down from my high place, wondering what "Tuskegee" meant for the vehicle driver, an older Black gentleman from Alabama. Does being Hebrew have anything to do with it? His answers need not be my own, yet surely there is more to be gained by asking more questions of each other and ourselves in this modern moment.

\section{Conclusions}

The causes and effects of public health crises, and the ethinic reasoning of groups are too complicated to be confined to a term. As scholars of religion find themselves in eruptive public spaces, will we resist the temptation to shift the conversation to definitions with which we are more comfortable? Or will we venture into disorder and think anew?

From the history of religions, we know better than to turn philological and pathological diagnoses into last words. And from this thought experiment, I think we see that there are things to learn from looking in the wrong place and the wrong time. Careful comparison and self-reflection can lead to the fruits of wise foolishness.

In the eruptive public space of the courtesy vehicle, an exchange with the driver pushed me to remember how the terms we think we know so well are always being signified and must be investigated. Even a well-worn term like "Hebrew" is full of nothing but interpretive possibility. Thinking further about the ethnic reasoning behind "Hebrews" and "religions" surfaced the politics of those identificatory claims obscured by convention. And renewed awareness of the racial history of Hebrew and Hebrews alike laid bare the hubris that inhibited my ability to perform my scholarly task in the courtesy vehicle.

Unable to truly return to the past, I wonder how I could have done right by the driver who was so kind to take me to my study. Sometimes I dare to wonder how he is doing today. Admittedly, it is far easier to just wonder how I could have done better.

On this, I keep returning not only to the courtesy vehicle, but also to the words of Kizzmekia Corbett, viral immunologist and team leader for the Moderna vaccine, the National Institutes of Health. Corbett says that instead of "vaccine hesitancy", we might think of Black people as exhibiting "vaccine inquisitiveness".

"When you call it inquisitiveness, you are giving patients the power to ask questions ... Oftentimes it is not that they're hesitant, bu that they just want to know about the vaccine, like what's in it, how it was developed, does it cause infertility-things like that". (D'arrigo 2021)

Comparatively speaking, I think the scholar of religion differs from the medical doctor. Unlike APA Distinguished Life Fellow and President-elect of the Black Psychiatrists of America Cythnia Turner-Graham, our job is not "to help give [patients] the best information [we] can so they can make the best decision for themselves" (D'arrigo 2021). But in eruptive public spaces, maybe our job is to help them ask questions befitting the ramifications of their answers-those we know and those we know humans can imagine. We can be diagnosticians of classification.

Funding: This research received no external funding.

Conflicts of Interest: The authors declare no conflict of interest. 


\section{References}

Alberts, Wanda. 2020. Good and bad, legitimate and illegitimate, religion in education. In Hijacked: A Critical Treatment of the Public Rhetoric of Good and Bad Religion. Edited by Leslie Dorrough Smith, Steffen Führding and Adrian Hermann. Sheffield: Equinox Publishing, pp. 205-11.

Altman, Michael J. 2019. "Religion, Religions, Religious" in America: Toward a Smithian Account of Evangelicalism. Method E Theory in the Study of Religion 31: 71-82.

Anderson, Victor. 1995. Beyond Ontological Blackness: An Essay on African-American Religious and Cultural Criticism. New York: Continuum.

Bain-Selbo, Eric. 2019. Affect Theory, Religion, and Sport. Religions 10: 457. [CrossRef]

Baker, Kelly J. 2011. Gospel According to the Klan: The KKK's Appeal to Protestant America, 1915-1930. Lawrence: University of Kansas Press.

Ben-Gurion, David. 1972. Letters to Paula. Tel Aviv: Am Oved, p. 75. First published 1947.

Benstein, Jeremy. 2013. On Root-What does the word 'Hebrew' mean? Haaretz. July 9. Available online: https://www.haaretz.com/ israel-news/culture/.premium-on-root-what-does-the-word-hebrew-mean-1.5293110 (accessed on 18 November 2021).

Blum, Edward J., and Paul Harvey. 2012. The Color of Christ: The Son of God and the Saga of Race in America. Chapel Hill: University of North Carolina Press.

Braun, Willi. 2020. Jesus and Addition to Origins: Toward an Anthropocentric Study of Religion. Edited by Russell T. McCutcheon. Sheffield: Equinox Publishing.

Buell, Denise Kimber. 2005. Why This New Race: Ethnic Reasoning in Early Christianity. New York: Columbia University Press.

Clark, Emily Suzanne. 2013. Noble Drew Ali's "Clean and Pure Nation". Novo Religio: The Journal of Alternative and Emergent Religions 16: 31-51. [CrossRef]

Cone, James H. 2019. Black Theology and Black Power, 50th Anniversary ed. Maryknoll: Orbis Books. First published 1969.

Curtis, Edward E., IV. 2002. Islamicizing the Black Body: Ritual and Power in Elijah Muhammad's Nation of Islam. Religion and American Culture 12: 167-96. [CrossRef]

Curtis, Susan. 1991. A Consuming Faith: The Social Gospel and Modern American Culture. Baltimore: The John Hopkins University Press.

D'arrigo, Terri. 2021. APA Fireside Chat addresses awareness about COVID-19 Vaccination. American Psychological Association. [CrossRef]

Dew, Spencer. 2019. The Aliites: Race and Law in the Religions of Noble Drew Ali. Chicago: University of Chicago Press.

Dillery, John. 2003. Putting Him Back Together Again: Apion historian, Apion grammatikos. Classical Philology 98: 383-90. [CrossRef]

Donner, Franklin J. 1980. The Age of Surveillance: The Aims and Methods of America's Political Intelligence System. New York: Alfred A. Knopf.

Dorman, Jacob S. 2007. "I Saw You Disappear with My Own Eyes": Hidden Transcripts of New York Black Israelite Bricolage. Novo Religio: The Journal of Alternative and Emergent Religions 11: 61-83. [CrossRef]

Driscoll, Christopher M., and Monica R. Miller. 2019. Method as Identity: Manufacturing Distance in the Academic Study of Religion. London: Lexington Books.

Gallagher, Edmon L. 2012. The language of Hebrew scripture and patristic biblical theory. In Hebrew Scripture in Patristic Biblical Theory: Canon, Language, Text. Leiden: Brill, pp. 105-42.

Goodwin, Megan. 2021. What does race have to do with "cults?". Medium, January 28. Available online: https://medium.com/cultssects / what-does-race-have-to-do-with-cults-29f66074cddf (accessed on 18 November 2021).

Gray, Fred D. 1998. The Tuskegee Syphilis Study: An Insider's Account of the Shocking Medical Experiment Conducted by Government Doctors against African American Men. Montgomery: NewSouth Books.

Harrison, Faye V. 2008. Outsider Within: Reworking Anthropology in the Global Age. Champaign: University of Illinois Press.

Harshav, Benjamin. 1993. Language in Time of Revolution. Berkeley: University of California Press.

Ho, Craig. 2002. The problem of historicity in Hebrew historiography and how to cope with it as Christians: A response "On Hebrew history". In Hebrew Origins: Historiography, History, Faith of Ancient Israel. Hong Kong: Chinese University of Hong Kong, pp. 66-75.

Horrell, David G. 2020. Ethnicity and Inclusion: Religion, Race, and Whiteness in Constructions of Jewish and Christian Identities. Grand Rapids: William B. Eerdmans.

Huang, Pien. 2021. 'You can't treat it if you can't empathize': Black doctors tackle vaccine hesitancy. NPR, January 21. Available online: https:/ / www.npr.org/sections/health-shots/2021/01/19/956015308/you-cant-treat-if-you-cant-empathize-blackdoctors-tackle-vaccine-hesitancy (accessed on 14 July 2021).

Jenkins, Morgan. 2021. Descendants of Tuskegee Syphilis Study Survivors Say It Was Nothing Like the Covid-19 Vaccine. Medium. Available online: https: / / zora.medium.com/descendants-of-the-tuskegee-syphilis-study-survivors-speak-out-on-the-covid19-vaccine-6bb800d1ad17 (accessed on 12 July 2021).

Johnson, Sylvester A. 2015. African American Religions, 1500-2000: Colonialism, Democracy, Freedom. Cambridge: Cambridge University Press.

Katz, Ralph V., Stephen Kegeles, Nancy R. Kressin, Lee Green, Sherman A. James, Min Qi Wang, Stefaine L. Russell, and Cristina Claudio. 2008. Awareness of the Tuskegee Syphilis Study and the US Presidential Apology and Their Influence on Minority Participation in Biomedical Research. American Journal of Public Health 98: 1137-42. [CrossRef] 
Keaten, Jamey, Maria Cheng, and John Leicester. 2020. WHO Declares Coronavirus a Pandemic, Urges Aggressive Action. March 11. Associated Press. Available online: https://apnews.com/article/united-nations-michael-pence-religion-travel-virus-outbreak52e12ca90c55b6e0c398d134a2cc286e (accessed on 1 July 2021).

Key, Andre E. 2014a. Toward a Typology of Black Hebrew Religious Thought and Practice. Journal of African Religions 2: 31-66. [CrossRef]

Key, Andre Key. 2014b. If thou do not hearken unto the voice of the Lord thy God: A critique of theodicy in Black Judaiasm. Black Theology 12: 267-88. [CrossRef]

LaRocca-Pitts, Beth. 2003. "These are your gods, O Israel": The challenge of reconstructing Israelite religion using both text and archaeology. In Between Text and Artifact: Integrating Archaeology in Biblical Studies Teaching. Atlanta: Society of Biblical Literature, pp. 53-65.

Lavizzo-Mourey, Risa, and David Williams. 2016. Being Black is bad for your Heath. U.S. News E World Report, April 14. Available online: https: / / www.usnews.com/opinion/blogs/policy-dose/articles/2016-04-14/theres-a-huge-health-equity-gap-betweenwhites-and-minorities (accessed on 1 July 2021).

Lawson, Sierra L., and Steven W. Ramey. 2018. Sourcing stereotypes: Constructing and challenging simplified knowledge. Culture $\mathcal{E}$ Religion: An Interdisciplinary Journal 19: 416-34. [CrossRef]

Lemeche, Niels Peter. 1992a. Habiru, Hapiru. In The Yale Anchor Bible Dictionary. New Haven: Yale University Press, vol. 3, pp. 6-10.

Lemeche, Niels Peter. 1992b. Hebrew. In The Yale Anchor Bible Dictionary. New Haven: Yale University Press, vol. 3, p. 95.

Levine, Daniel B. 1993. Hubris in Josephus' "Jewish Antiquities” 1-4. Hebrew Union College Annual 64: 51-87.

Lincoln, Bruce. 2018. Apples and Oranges: Explorations in, on, and with Comparison. Chicago: University of Chicago Press.

Long, Charles H. 2018. The gift of speech and the travail of language. In Ellipsis: The Collected Writings of Charles H. Long. New York: Bloomsbury, pp. 403-12. First published 1993.

Magid, Shaul, and Annette Yoshiko Reed. 2017. Introduction: Forum on Cynthia Baker. Jew. Marginalia- Los Angeles Review of Books. Available online: http:/ / marginalia.lareviewofbooks.org/introduction-forum-on-cynthia-baker-jew/ (accessed on 11 July 2021).

Martin, Lerone. 2018a. Bureau Clergyman: How the FBI Colluded with an African American Televangelist to Destroy Dr. Martin Luther King, Jr. Religion and American Culture: A Journal of Interpretation 28: 1-51. [CrossRef]

Martin, Lerone. 2018b. The FBI. The Immanent Frame: Secularism, Religion and the Public Sphere, March 13. Available online: https: / / tif.ssrc.org/2018/03/13/the-fbi/ (accessed on 5 July 2021).

Martin, Michel. 2008. In Character-Why African-Americans loathe “Uncle Tom”. NPR, July 30. Available online: https:/ /www.npr. org / templates/story/story.php?storyId=93059468 (accessed on 1 July 2021).

Masuzawa, Tomoko. 2005. The Invention of World Religions, or, How European Universalism Was Preserved in the Language of Pluralism. Chicago: University of Chicago Press.

McCutcheon, Russell T. 2017. Afterword: Express yourself. In Fabricating Identities. Edited by Russell T. McCutcheon. Sheffield: Equinox, pp. 139-64.

Milligan, Amy K. 2019. Jewish Bodylore: Feminist and Queer Ethnographies of Folk Practices. London: Lexington Books.

Na'aman, Nadav. 1986. Habiru and Hebrews: The Transfer of a Social Term to the Literary Sphere. Journal of Near Eastern Studies 45: 271-88. [CrossRef]

Newton, Richard. 2017. The African American Bible: Bound in a Christian Nation. Journal of Biblical Literature 136: 221-28. [CrossRef]

Newton, Richard. 2020. Can We Be Colleagues. Bulletin for the Study of Religion 49: 1-2. [CrossRef]

Nye, Malory. 2019. Decolonizing the Study of Religion. Open Library of Humaniteis 5: 43. [CrossRef]

Patton, Laurie L. 2019. Who Owns Religion? Scholars and Their Publics in the Late Twentieth Century. Chicago: University of Chicago Press.

Paul, Charlotte, and Barbara Brookes. 2015. The Rationalization of Unethical Research: Revisionist Accounts of the Tuskegee Syphilis Study and the New Zealand "Unfortunate Experiment". American Journal of Public Health 105: e12-e19. [CrossRef]

Pillon, Dennis. 2021. 'I'm sorry, but it's too late': Alabama doctor on treating unvaccinated, dying COVID patients". AL.com, July 21. Available online: https: / www.al.com/news/2021/07/im-sorry-but-its-too-late-alabama-doctor-on-treating-unvaccinateddying-covid-patients.html (accessed on 22 October 2021).

Pinn, Anthony B. 2003. Terror and Triumph: The Nature of Black Religion. Minneapolis: Fortress Press.

Pinn, Anthony B. 2017. On the question at the end of theodicy. Religions 8: 268. [CrossRef]

Poythress, Norman, Monica Epstein, Paul Stiles, and John F. Edens. 2011. Awareness of the Tuskegee Syphilis Study: Impact on Offenders' Decisions to Decline Research Participation. Behavioral Sciences and the Law 29: 821-28. [CrossRef]

Reinhartz, Adele. 2017. The JBL Forum, an Occasional Exchange: Black Lives Matter for Critical Biblical Scholarship. Journal of Biblical Literature 136: 203. [CrossRef]

Reinhartz, Adele. 2020. The Hermeneutics of Chutzpah: A Disquisition on the Value/s of 'Critical Investigation of the Bible. 2020 Society of Biblical Literature Presidential Address. Available online: https://www.sbl-site.org/meetings/2020PresidentialAddress.aspx (accessed on 18 November 2021).

Reverby, Susan M. 2009. Examining Tuskegee: The Infamous Syphilis Study and Its Legacy. Chapel Hill: The University of North Carolina Press.

Rose, Maya C., Jessica E. Brodsky, Elizabeth S. Che, and Patricia J. Brooks. 2021. Teaching about Systemic Ethical Misconduct Increases Awareness of Ethical Principles: A Replication and Extension of Grose-Fifer's (2017) Tuskegee Role-Play Activity. Teaching of Psychology. [CrossRef] 
Sáenz-Badillos, Angel. 1996. A History of the Hebrew Language. New York: Cambridge University Press.

Sanders, Seth L. 2009. The Invention of Hebrew. Champaign: University of Illinois Press.

Sasson, Jack. 2002. Hebrew Origins: Historiography, History, Faith of Ancient Israel. Hong Kong: Chinese University of Hong Kong.

Schaefer, Donovan O. 2019. Whiteness and Civilization: Shame, Race, and the Rhetoric of Donald Trump. Communication and Critical/Cultural Studies 17: 1-18. [CrossRef]

Sernett, Milton C. 1977. Bound for the Promised Land: African American Religion and the Great Migration. Durham: Duke University Press. Shapiro, Ari, and Farah Eltohamy. 2021. Alabama official on vaccine rollout: 'How can this disparity exist in this country? NPR, March 11. Available online: https:/ / www.npr.org/sections/coronavirus-live-updates/2021/03/10/975692487/alabama-official-onvaccine-rollout-how-can-this-disparity-exist-in-this-country (accessed on 12 July 2021).

Shapiro, Ari. 2021. Twice as many white Alabamaians are getting Covid-19 Vaccinations as Black Alabamians. NPR. Available online: https:/ / www.npr.org/2021/03/10/975769774/twice-as-many-white-alabamans-are-getting-covid-19-vaccinationsthan-black-alaba (accessed on 12 July 2021).

Sisk, Taylor. 2021. Black vaccine hesitance: “We've Got to go to Church". Medpage Today, February 26. Available online: https: //www.medpagetoday.com/special-reports/exclusives/91365 (accessed on 18 November 2021).

Smith, Jonathan Z. 1982. Imagining Religion: From Babylon to Jonestown. Chicago: University of Chicago Press.

Smith, Jonathan Z. 2004. Religion, religions, religious. In Relating Religion: Essays in the Study of Religion. Chicago: University of Chicago Press, pp. 179-98. First published 1998.

Smith, Matthew J. 2021. The everyday ecology of Black religion. The Immanent Frame, February 21. Available online: https:/ / tif.ssrc. org/2021/02/04/the-everyday-ecology-of-antiblack-religion/ (accessed on 26 October 2021).

The Christian Century. 2000. The Christian century: Take two. Christian Century, January 26, 77-79.

Toulouse, Mark. 2000. The origins of the Christian Century, 1884-1914. Christian Century, January 26, 80-83.

Touna, Vaia. 2017. Fabrications of the Greek Past: Religion, Tradition, and the Making of Modern Identities. Leiden: Brill.

Tounsel, Christopher. 2020. "Negro Canaan": Cotton, Tuskegee, and the Anglo-Egyptian Sudan. Journal of African American History 105: 28-55. [CrossRef]

Turner, Patricia. 1994. Ceramic Uncles and Celluloid Mammies: Black Images and Their Influence on Culture. Charlottesville: University of Virginia.

Valone, David A. 1996. Language, Race, and History: The Origin of the Whitney-Müller Debate and the Transformation of the Human Sciences. Journal of the History of the Behavioral Sciences 32: 119-34. [CrossRef]

Vayntrub, Jacqueline. 2021. Hebrew. In How Literatures Begin: A Global History. Edited by Joel B. Lande and Denis Feeney. Princeton: Princeton University Press.

Walsh, Robin Faith. 2021. The Origins of Early Christian Literature: Contextualizing the New Testament within Greco-Roman Literary Culture. Cambridge: Cambridge University Press.

Waterhouse, S. Douglas. 2001. Who are the Habiru of the Amarna Letters. Journal of the Adventist Theological Society 12: 31-42.

Weisenfeld, Judith. 2016. New World A-Coming. New York: New York University Press.

Weitzman, Steven P. 2013. Religious Studies and the FBI: Adventures in Academic Interventionism. Journal of the American Academy of Religion 81: 959-95. [CrossRef]

Whitney, William D. 1881. On the So-called Science of Religion. The Princeton Review 57: 429-52.

Wilkerson, Isabel. 2010. The Warmth of Other Suns: The Epic Story of America's Great Migration. New York: Random House.

Wimbush, Vincent L. 2017. Scripturalectics: The Management of Meaning. New York: Oxford University Press. 